\title{
Article
}

\section{Factors influencing implementation of aerobic exercise after stroke: a systematic review}

Gaskins, Nicola, Bray, Emma, Hill, James Edward, Doherty, Patrick J., Harrison, Alexander and Connell, Louise

Available at http://clok.uclan.ac.uk/31081/

Gaskins, Nicola, Bray, Emma ORCID: 0000-0001-9882-3539, Hill, James Edward ORCID: 0000-0003-1430-6927, Doherty, Patrick J., Harrison, Alexander and Connell, Louise ORCID: 0000-0002-0629-2919 (2021) Factors influencing implementation of aerobic exercise after stroke: a systematic review.

Disability and Rehabilitation, 43 (17). pp. 2382-2396. ISSN 0963-8288

It is advisable to refer to the publisher's version if you intend to cite from the work. http://dx.doi.org/10.1080/09638288.2019.1704075

For more information about UCLan's research in this area go to http://www.uclan.ac.uk/researchgroups/ and search for <name of research Group>.

For information about Research generally at UCLan please go to http://www.uclan.ac.uk/research/

All outputs in CLoK are protected by Intellectual Property Rights law, including Copyright law. Copyright, IPR and Moral Rights for the works on this site are retained by the individual authors and/or other copyright owners. Terms and conditions for use of this material are defined in the policies page.

\section{CLoK}

Central Lancashire online Knowledge www.clok.uclan.ac.uk

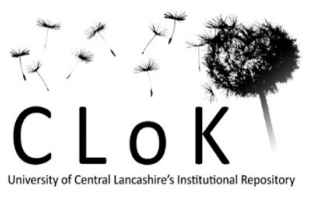


Title:

Factors influencing implementation of aerobic exercise after stroke: A systematic review

\section{Running Head:}

Implementation of aerobic exercise after stroke

\section{Article Category:}

Review

\section{Authors:}

Nicola J Gaskins ${ }^{1}$, Emma Bray ${ }^{1}$, James E Hill ${ }^{1}$, Patrick J Doherty ${ }^{2}$, Alexander Harrison ${ }^{2}$, Louise A Connell ${ }^{1}$

${ }^{1}$ Faculty of Health and Wellbeing, University of Central Lancashire, Preston, United Kingdom

${ }^{2}$ Department of Health Sciences, University of York, York, United Kingdom

\section{Corresponding Author:}

Dr Louise Connell

Reader in Rehabilitation

Faculty of Health \& Wellbeing,

University of Central Lancashire

Preston,

PR1 2HE,

United Kingdom

laconnell@uclan.ac.uk

+44 (0)1772895119

https://orcid.org/0000-0002-0629-2919 


\section{Abstract:}

Title

Factors Influencing Implementation of Aerobic Exercise after Stroke: A Systematic Review

\section{Objectives:}

This systematic review aimed to explore the perspectives of healthcare, exercise, and fitness professionals working with people post-stroke regarding the factors affecting the implementation of aerobic exercise after stroke.

\section{Data Sources:}

OVID SP MEDLINE, OVID SP EMBASE and CINAHL were searched from inception to December 2018 using a combination of search terms with synonyms of stroke, aerobic exercise and barriers/facilitators.

\section{Review methods:}

Studies focusing on the factors affecting implementation of aerobic exercise after stroke from staff perspectives were included with no restriction on the types of study design. For inclusivity, a broad definition of aerobic exercise was used.

Review authors independently extracted data from included studies using domains from the Consolidated Framework for Implementation Research, then synthesised using a framework synthesis approach. Retrospective automated screening was conducted using Rayyan software.

\section{Results}

Twenty studies were included. Four reported on implementation of aerobic exercise, sixteen on general exercise interventions, all post-stroke. Factors identified as influencing implementation of aerobic exercise after stroke included professionals' self-efficacy and knowledge about stroke, patients' needs, communication and collaboration within and between organisations and resources such as equipment, staff and training.

\section{Conclusions}

Key factors influencing the implementation of aerobic exercise after stroke included characteristics of the staff and intervention and system-level issues, some of which are modifiable. Further research 
should evaluate strategies which specifically target these modifiable factors to facilitate implementation in practice.

\section{Keywords:}

Stroke; exercise; rehabilitation; implementation; Attitude of Health Personnel*; Health Knowledge, Attitudes, Practice; systematic review;

Word Count: 3978 


\section{Introduction}

An estimated 7 million people in the United Kingdom (UK) have cardiovascular disease [1]. Over 1.3 million have survived a stroke or transient ischaemic attack [1]. This burdens the UK considerably in terms of both health and economic costs [1-3]. Stroke patients often suffer from poor cardiovascular health and physical, psychosocial and cognitive impairments $[3,4]$ and are at increased risk of further cardiovascular events [5]. Aerobic exercise is an evidence-based intervention which promotes cardiovascular health [6] and is recommended for both healthy populations [7] and specific conditions, including stroke [8-11]. It is defined as any activity which uses large muscle groups, is rhythmic and can be sustained continuously [12], for example, walking, cycling, swimming and dancing. Aerobic exercise is beneficial during all phases of stroke including acute [13] subacute [14] and chronic [15], and should be included throughout stroke rehabilitation [11]. Research has shown improvements in mobility and walking speed [16,17], balance [18], cognition [17], blood pressure [19,20], and a reduction in disability [21]. However, despite guideline recommendation [22-25] and robust evidence supporting aerobic exercise in stroke rehabilitation $[11,21,26,27]$, the majority of patients in stroke rehabilitation spend most of their time sitting or lying [28] with minimal focus on aerobic fitness [29]. This chronic inactivity leads to a negative cycle of deconditioning, decreased function and increased chance of further cardiovascular events [30]. To date, research has tended to focus on the delivery of additional exercise programmes of various formats on patient outcome [31,32] (e.g. seated vs standing aerobic exercise [33], cycling [34], walking [35], group exercise [36]), with scant attention given to how to implement aerobic exercise into stroke rehabilitation.

Despite the recognition by staff that aerobic exercise is important in stroke rehabilitation [37], clinical implementation remains challenging [38]. This systematic review aimed to collate existing evidence and explore the factors influencing implementation of 
aerobic exercise after stroke from the perspectives of staff whose roles were within healthcare, exercise, or fitness settings.

\section{Methods:}

The review was registered with PROSPERO, the international prospective register of systematic reviews (registration number CRD42018099579), and reported in accordance with the Preferred Reporting Items for Systematic Reviews and Meta-Analyses (PRISMA) statement [39].

\section{Search Strategy}

The SPIDER (Sample, Phenomenon of Interest, Design, Evaluation, Research type) search tool, specifically adapted from the PICO (Population/problem, Intervention/exposure, Comparison, and Outcome) tool for use in qualitative research [40], was used to develop an effective search strategy. The three domains identified using the SPIDER search tool [40] for this review were; the sample (patients with stroke), the phenomenon of interest (aerobic exercise) and evaluation (of the barriers and facilitators from a healthcare, exercise and fitness professionals' perspective). Synonyms of each domain and corresponding full search strategy are shown in supplementary material.

Reference lists of included full text papers were scanned to identify any further potential studies ("snowballing") [41]. In the case of abstracts identified as potentially relevant but with no accessible full text available, efforts were made to contact authors.

\section{Data Sources:}

The electronic databases OVID SP MEDLINE, OVID SP EMBASE and CINAHL were searched from inception until December 2018. Articles were limited to the English language 
as resources were not available for foreign language translation. Search hits were imported into EndNote where duplicates were removed.

\section{Selection criteria}

Studies with a formal objective which involved the exploration of factors (barriers and/or facilitators) affecting the implementation of aerobic exercise from the perspectives of staff were included. No restrictions were imposed based on age, stroke characteristics or time since stroke. A scoping exercise indicated that, due to issues with reporting and defining of interventions, the definition of 'aerobic exercise' needed to be comprehensive. Therefore, any exercise interventions which were potentially aerobic in nature, following the broad definition provided in the introduction, but not reported using the term 'aerobic exercise' were included, for example, exercise after stroke, community-based exercise, treadmill training.

The population were any staff working within stroke-related healthcare, exercise, or fitness settings, with no restrictions based on qualifications or experience. Please note that henceforth, the term 'physiotherapists' refers to both 'physiotherapists' and 'physical therapists', and the term 'exercise professionals' includes 'exercise professionals', 'fitness instructors' and 'kinesiologists'.

\section{Screening}

A single reviewer (NG) completed the title and abstract screening. Articles relevant for inclusion were each independently screened by two of the three authors (NG and LC or EB). Uncertainty was resolved by discussions, and if consensus could not be reached, arbitration was carried out by the third author. Reasons for exclusion at the full text screening stage were documented. 


\section{Post-Protocol Automated Screening}

Following completion of data analysis, the reviewers chose to add a post-protocol adaptation in the form of retrospective automated screening using Rayyan [42,43], a web and mobile app. Automated screening can optimise the results of the screening process by increasing recall of relevant studies, thereby strengthening a review [44]. The original search records were uploaded to Rayyan, with the included and excluded studies indicated. The software then calculated and rated how likely the excluded studies were to be related to the included studies. The 200 most relevant studies were then re-screened by NG.

\section{Data Extraction and Synthesis}

All papers were imported into NVIVO 12 Pro, a data analysis software tool. Two of three review authors (NG,LC,EB) independently extracted data from each of the included studies using domains from the Consolidated Framework for Implementation Research [45], a pragmatic taxonomy of the factors that influence implementation consisting of five domains: characteristics of the intervention, inner setting, outer setting, characteristics of individuals, and processes. Nodes for data extraction were as per the Consolidated Framework for Implementation Research (table 1) with extra nodes created as required. Initially, one study was coded by all three reviewers followed by a discussion to ensure that interpretation of the framework was consistent. Results were then synthesised using a framework synthesis approach [46].

[Table 1 near here]

Care was taken during data analysis and synthesis to refer back to the primary data to ensure 
that there was no loss of context or misinterpretation of results [47]. Regular team meetings focusing on discussion of the evidence were carried out to facilitate a shared understanding as recommended in the Cochrane guidance [47].

\section{Quality assessment and Sensitivity Analysis}

Excluding studies risks the loss of valuable data and the contribution of individual studies may only become apparent during data synthesis [48], hence no studies were excluded on the basis of quality. We included all studies, and then undertook a sensitivity analysis after completion of the data synthesis to ensure that any valuable contributions from individual studies were included. This process involved extracting data from the conference abstracts separate to the full texts and then comparing these with the full texts' data.

\section{Reflexivity}

The lead researcher (NG) is a physiotherapist with clinical experience in both stroke and cardiac rehabilitation. Three other members of the team also have a background in physiotherapy: LC is a clinician-scientist specialising in implementation research and stroke rehabilitation, PD has over 20 years of working experience as a clinical academic in cardiac rehabilitation and Director of the National Audit for Cardiac Rehabilitation and JH is a senior fellow in evidence synthesis with experience of systematic reviewing and automated screening. EB is a chartered psychologist with an interest in health interventions and experience of designing and conducting NHS-based health interventions, and AH a Health Services researcher specialising in modes of delivery in cardiac rehabilitation. 


\section{Results}

\section{Study identification}

A total of 11,683 hits were identified through the search strategy, of which 63 progressed to full text review including 4 additional texts ( 3 abstracts and 1 full text) identified through automated screening. A total of 20 studies were identified for the review which comprised of eleven full text articles and nine conference abstracts (figure 1). A summary of the included studies is shown in table 2 .

[Figure 1 near here]

[Table 2 near here]

\section{Description of included studies}

Included studies were conducted in North America $(n=10)$, Europe $(n=7)$ and Australia $(n=3)$. Studies with the greatest number of participants were generally from North America and the Netherlands. All were set within either healthcare, exercise, or fitness settings including hospitals, primary practice, leisure services and charities. Four of the North American studies $[37,38,49,50]$ provided data on the factors perceived by physiotherapists $[37,38,50]$ and clinicians (specific profession not given) [49] to influence implementation of aerobic exercise after stroke. The remaining sixteen studies in this review reported on the barriers and/or facilitators to participation in, or implementation of, an exercise intervention after stroke from the perspectives of staff. Examples of these interventions were 'exercise programme' [51], 'community-based exercise' [52,53], 'high intensity interval training' [54] and 'fitness programmes' [55]. These were included under this review's broad definition of aerobic exercise to avoid the possibility of excluding valuable data. Three of these sixteen studies involved service providers, fitness facilities and cardiac rehabilitation programmes [55-57]. 
Staff included healthcare professionals [52,53,58-62], physiotherapists $[54,63,64]$ and fitness instructors [53,65], cardiac and stroke rehabilitation teams [66], exercise professionals $[51,62]$ and others $[53,55-57,62]$. The views of physiotherapists $(n=909)$ were predominant with a lesser number of exercise professionals $(n=114)$, medical staff $(n=8)$ and nurses $(=11)$ represented. The number and/or specific profession of participants were not reported in six of the abstracts $[49,58,60-62,66]$.

\section{Sensitivity analysis}

The sensitivity analysis conducted on the conference abstracts $(n=9)$ revealed that, despite containing less methodological detail, they either confirmed or added depth to the findings and added valuable insight. For example, confirming the need for specialist staff to help implement the intervention post-stroke into an existing model (in this case, cardiac rehabilitation) [66] and the challenge of integrating exercise testing and prescription into patient and clinician schedules [49].

\section{Factors identified as influencing implementation}

The factors influencing implementation, derived from the Consolidated Framework for Implementation Research, are summarised with identification of the source references in table 3. The following descriptions have been presented as per the framework domains of Intervention Characteristics, Outer Setting, Inner Setting and Characteristics of Individuals.

[Table 3 near here]

\section{Intervention Characteristics}


This domain relates to the attributes of the intervention which have been shown to influence the effectiveness of implementation. The importance of being able to adapt the intervention for stroke patients, the format and prescriptiveness of the intervention, as well as the number of steps and cost required to implement were the main 'intervention characteristics' perceived by staff within healthcare, exercise, and fitness settings.

Adapting exercise interventions by having access to suitable adaptive equipment for screening for safety, and for individual exercise prescription was a need identified by clinicians, physiotherapists and exercise professionals [37,49,51], for example, body-weight supported treadmills and cycle ergometers. This is because use of standard exercise equipment may be challenging for some people after stroke depending on physical and cognitive abilities [65]. A suitable accessible physical space and appropriate environment were factors reported by exercise professionals and healthcare professionals $[51,53]$. Depending on patients' physical and cognitive abilities, specialist stroke or additional staff may also be required during the delivery of the intervention $[57,66]$. The potential number of professionals involved in implementation added to the complexity [37,61], with Miller et al (2017) [61] advocating an interdisciplinary approach to ensure success. Screening to determine whether aerobic exercise should be prescribed to an individual and its required resources also added to the complexity [37].

The potential cost of providing necessary extra resources was also identified as a factor, for example, concerns of self-employed fitness instructors about the source of funding for training in stroke $[51,65]$ and funds to sustain a community-based exercise programme [53].

\section{Outer Setting}


The needs of the patients and networking between organisations were factors in the 'outer setting'.

Concerns about the varied physical and cognitive needs and comorbidities of the patients and the impact of this on ability to participate in aerobic exercise were reported by physiotherapists $[37,38,50,54]$. To maintain patient safety, exercise professionals perceived that greater levels of supervision may be required, as well as adaptive equipment $[51,61,65]$. Physiotherapists perceived that the patient may be at risk of a cardiac event during the intervention [37,50], and, amongst exercise professionals, there was a fear of making the patient worse [51] . One UK study [66] noted social and cultural barriers to implementation of aerobic exercise whilst health care professionals in Canada noted language skills as a barrier [52]. Accessibility to, and inclusivity of services varied depending partly on how ambulatory the patient was and how complex their needs were $[53,56]$. An example of this was in Exercise after Stroke services in Scotland where there was a greater provision for ambulatory stroke survivors rather than those with complex disabilities [56].

The rehabilitation goals and motivation of the patients were found to be an area of conflicting opinion. Physiotherapists reported that aerobic fitness was not identified as a patient goal [38] and some healthcare professionals (physiotherapists, kinesiologists, physicians and nurses) $[52,59]$ reported that patients were perceived to have a lack of motivation, whereas conversely, cardiac rehabilitation and stroke teams reported that patients were generally motivated after stroke [66].

The development of networking and skill-sharing between organisations can facilitate implementation. Examples of this include liaison between physiotherapists and fitness instructors during patients' transition from the health service to exercise on prescription in leisure centres in the UK $[51,65]$ and in a healthcare-recreation partnership involving delivery of exercise programmes in community centres in Canada [53]. In contrast, American 
outpatient physiotherapists reported a lack of knowledge regarding suitable community-based exercise programmes for people post-stroke [38].

\section{Inner Setting}

Staff recognised that there is a definite need for sufficient resources including staff, training, equipment and space, as well as accessibility to appropriate screening and exercise testing to implement aerobic exercise within the stroke population. A culture of communication and collaboration within organisations would aid the sharing of knowledge between professions and services, facilitate methods of onward referral to other services and work to ascertain how the intervention would fit into the individuals' role and responsibilities. The "Together in Movement and Exercise" [67] collaboration is an example of knowledge-sharing between physiotherapists and fitness instructors which facilitates implementation of exercise programmes but which still faces challenges to sustaining collaboration and communication between the organisations involved [53].

There was an acknowledgement amongst physiotherapists [37,38] that aerobic exercise after stroke is desirable, even amongst those who were not currently providing this. Exercise professionals [51], physiotherapists[50] and cardiac and stroke rehabilitation teams [66] displayed a willingness to engage with the intervention through training, one example being physiotherapists providing training on stroke to fitness instructors within the Exercise on Prescription setting [65]. The perceived need for further information, knowledge and training about stroke was strongly expressed by physiotherapists, exercise professionals, rehabilitation clinicians and fitness instructors [50,51,56,61,64-66]. Exercise professionals were interested in training on safety, the physical and cognitive aspects of stroke, adaptive exercise and equipment and communication [51] and physiotherapists wanted to improve their skills to incorporate aerobic exercise into stroke rehabilitation [50]. The need for 
suitable equipment was a recurring factor amongst these same staff groups; one study noted that standard exercise equipment may not be appropriate for some patients and led to physiotherapists referring only more able patients to gyms [65]. A lack of time to incorporate the intervention into their practice was cited by physiotherapists $[38,50]$ and exercise professionals [51].

The structural characteristics of the organisation referred to in the literature included the organisation of the service and staffing as well as service provision for people post-stroke and the geographical areas covered by these services. For example, in Scotland the reported number of Exercise after Stroke services only equates to less than one per 7000 stroke survivors [56]. Provision of funding for specialist training and professional certification was an identified incentive for exercise professionals $[51,65]$ to implement the intervention. Another factor was funding models which influenced organisations' service provision $[55,63]$.

\section{Characteristics of Individuals}

The individuals' knowledge and beliefs about the intervention played an important role in implementation. Their self-efficacy (a person's belief in their own ability to carry out courses of action to achieve goals) and other personal attributes influenced how likely they were to prescribe aerobic exercise.

It was generally agreed by physiotherapists that aerobic exercise was important and should be prescribed post-stroke [37,38,50] although not all exercise professionals [65] or physiotherapists $[37,38]$ possessed factual knowledge about the intervention in relation to screening, prescription and guidelines. A fear of liability and of making the patients worse was identified as a barrier amongst some exercise professionals, especially those who lacked training on stroke [51], whereas potential cardiovascular risk to the patient was a barrier for 
physiotherapists in two Canadian studies [37,50]. Concerns about the ability [37] and motivation [59] of their patients to participate in aerobic exercise after stroke were raised by physiotherapists, and nurses, allied health professionals and medical staff respectively. Some physiotherapists and exercise professionals expressed confidence in their own ability to prescribe the intervention for people post-stroke whilst others did not $[38,66]$.

Physiotherapists and exercise professionals displayed a willingness and interest in learning and in improving their skills to facilitate implementation [50,51]. For example, exercise professionals identified a need for training on psychological problems post-stroke [51]. Exercise professionals agreed that stroke-specific training would lead to improvements in safety [51] and even those with experience of working with people with stroke reported that further training would be of benefit [65].

\section{Non-Consolidated Framework for Implementation nodes}

These nodes, for example, 'content of aerobic exercise', created during data extraction were identified as descriptors rather than findings.

\section{Discussion}

The main factors perceived by staff as influencing the implementation of aerobic exercise post-stroke were staff self-efficacy, their beliefs about the intervention and their patients' needs, and system-level issues relating to staffing, resources, knowledge and training. Twenty studies were identified, predominantly from a North American and physiotherapists' perspective, with $25 \%(\mathrm{n}=4)$ exploring the implementation of aerobic exercise post-stroke. The remaining studies $(n=16)$ involved implementation of other exercise interventions after stroke under this review's broad definition of aerobic exercise. 
The quality of a review relies on the data reported within the primary studies [68]. A lack of comprehensibility in the exercise intervention descriptions in sixteen of the studies led to difficulties in ascertaining whether aerobic exercise was included. Improved reporting which clarified the intervention would have eliminated the need to adopt a broad definition of aerobic exercise for this review [69]. Similar reporting challenges were found with respect to detail regarding staff and setting. Initiatives such as the template for intervention description and replication (TIDieR) checklist [70], which has been developed as a template for intervention description and replication in response to the poor quality in reporting of interventions, may help overcome some of these issues for future reviews.

The Consolidated Framework for Implementation Research had been used successfully and meaningfully in other areas [71] but not in the context of exercise implementation within stroke services. A systematic review of use of this framework reported that it has mostly been used retrospectively in the post-implementation phase [71]. The advantages of using this framework prior to intervention implementation include the identification of potential barriers, appropriate selection of implementation strategy and adaptation of the strategy to maximise likelihood of success [71]. The information identified in this review regarding the potential barriers to implementing aerobic exercise after stroke can be used to facilitate the steps to successful implementation and inform the direction of future research.

The factors identified are not unique to the implementation of exercise in the stroke context [72-75]. Similar factors including patient needs, staff knowledge and beliefs and resources have been identified within rheumatology, weight management and implementation of evidence-based practices in healthcare $[72,74,75]$. As such, these factors may be relevant to other long-term conditions in the context of multi-morbidities. 
Factors such as staffing, equipment, training and staff self-efficacy are potentially modifiable depending on the specific individual settings, staffing profiles, knowledge, experience and support within the broad range of staff groups. Criteria such as APEASE (Acceptability, Practicability, Effectiveness/cost-effectiveness, Affordability, Safety/sideeffects, Equity) [76], which were developed for use with behaviour change interventions, may provide a starting point for prioritising which modifiable factor(s) to target. These criteria indicate that factors around affordability, practicability, effectiveness and costeffectiveness, acceptability, side-effects/safety and equity should be considered when designing or evaluation interventions. Aerobic exercise is a proven effective intervention after stroke, however, its effectiveness is irrelevant if it cannot be afforded, implemented as designed or by the appropriate professionals, or if it is not accepted by staff and people poststroke.

Physiotherapists and exercise professionals in this review reported a need for knowledge and training on stroke and appropriate exercise interventions. There are links between staff beliefs and knowledge which have a subsequent influence on implementation [77,78]. Van Kessel et al [78] found that physiotherapists' knowledge and beliefs influenced their implementation of circuit classes and seven-day therapy in stroke rehabilitation. However, changing behaviour is complex and education in isolation is likely to be ineffective [79]. Other strategies must therefore be considered, such as provision of support for staff through facilitation, tailoring of strategies to staff groups and settings and use of care pathways or a combination of these [79].

Successful implementation of interventions requires sufficient resources to address the needs of a population [74]. Increasing demands on resources within current systems mean that alternative mechanisms of delivery of interventions need to be explored. This could 
include, for example, resource reallocation or skill-sharing amongst colleagues both within and between organisations.

There is also a lack of clarity as to whose role it is to initiate and implement change. This is likely to vary from one setting and staff group to the next. This review identifies the involvement of a range of staff from budget holders and senior managers to staff delivering the intervention. Changes are often led by clinicians [73] and there is evidence that middle management [80], leadership engagement and collaboration between organisations are important for successful implementation [74]. One possible means of facilitating this process is via co-production where stakeholders work collaboratively to facilitate service re-design [62].

Factors influencing implementation as perceived by staff have been identified in this review, some of which, such as knowledge and self-efficacy could be modified. To facilitate the complex process of implementation of aerobic exercise after stroke, further research should evaluate strategies which target these modifiable factors. Recent research aiming to assist with appropriate selection of theories and frameworks to plan and guide implementation could be used [81-83]. The cost of modifying and sustaining these changes should also be investigated due to the overlapping of health and leisure organisations and the continuous state of flux of health and political systems.

\section{Strengths and Limitations}

There were several limitations to this review. These included the low number of full-text studies ( $\mathrm{n}=11)$, the predominance of healthcare professionals' views, geographical coverage limited to the three continents of North America, Europe and Australia and limiting the language to articles in English. Aerobic exercise was expressly reported as the intervention in just four studies, all of which were North American. These factors potentially limit the generalisability of the findings and highlight the shortfall in research in this area. 
The use of automated screening with the Rayyan app [42] enhanced the screening process. This efficient, accurate, user-friendly addition to manual screening, which could be used as an alternative to this, also has the benefit of free availability. In future, the option of using automated screening as a tool for enhanced screening during systematic reviewing should be considered.

A further strength of this review involved the use of an implementation framework. This ensured a comprehensive, structured and consistent approach to considering the factors influencing implementation.

\section{Conclusion}

This is the first systematic review to explore the factors that staff identified as influencing implementation of aerobic exercise after stroke. Characteristics of staff (self-efficacy, beliefs about the intervention and their patients' needs) and system-level issues (staffing, resources and training) were identified as key factors. Factors such as knowledge, training and beliefs are modifiable. Further research should evaluate strategies which specifically target these modifiable factors to facilitate implementation in practice.

\section{Accompanying statements}

This work was supported by a Grant from the Chartered Society of Physiotherapy Charitable Trust (Grant number PRF/17/B01).

The authors thank Janet Reed, information specialist at UCLan, for her assistance with the search strategy. 


\section{References}

1. British Heart Foundation. British Heart Foundation UK Factsheet 2018. https://www.bhf.org.uk/what-we-do/our-research/heart-statistics2018.

2. Bhatnagar $\mathrm{P}$, Wickramasinghe $\mathrm{K}$, Williams J, et al. The epidemiology of cardiovascular disease in the UK 2014. Heart. 2015 Aug;101(15):1182-9.

3. Stroke Association. State of the Nation Stroke Statistics. https://www.stroke.org.uk/system/files/sotn 2018.pdf2018.

4. Baert I, Daly D, Dejaeger E, et al. Evolution of Cardiorespiratory Fitness After Stroke: A 1-Year Follow-Up Study. Influence of Prestroke Patients' Characteristics and Stroke-Related Factors. Archives of Physical Medicine \& Rehabilitation. 2012;93(4):669-676.

5. Burn J, Dennis M, Bamford J, et al. Long-term risk of recurrent stroke after a first-ever stroke. The Oxfordshire Community Stroke Project. Stroke. 1994 Feb;25(2):333-7.

6. Patel $\mathrm{H}$, Alkhawam $\mathrm{H}$, Madanieh $\mathrm{R}$, et al. Aerobic vs anaerobic exercise training effects on the cardiovascular system. World J Cardiol. 2017;9(2):134-138.

7. Garber CE, Blissmer B, Deschenes MR, et al. American College of Sports Medicine position stand. Quantity and quality of exercise for developing and maintaining cardiorespiratory, musculoskeletal, and neuromotor fitness in apparently healthy adults: guidance for prescribing exercise. Med Sci Sports Exerc. 2011 Jul;43(7):1334-59.

8. Thomas D, Elliott EJ, Naughton GA. Exercise for type 2 diabetes mellitus. Cochrane Database of Systematic Reviews. 2006 (3).

9. Kramer MS, McDonald SW. Aerobic exercise for women during pregnancy. Cochrane Database of Systematic Reviews. 2006 (3).

10. Meneses-Echávez JF, González-Jiménez E, Ramírez-Vélez R. Supervised exercise reduces cancer-related fatigue: a systematic review. Journal of Physiotherapy. 2015 2015/01/01/;61(1):3-9.

11. Billinger SA, Arena R, Bernhardt J, et al. Physical activity and exercise recommendations for stroke survivors: a statement for healthcare professionals from the American Heart Association/American Stroke Association. Stroke. 2014 Aug;45(8):2532-53.

12. Swain DP, Brawner CA, Medicine ACoS. ACSM's resource manual for guidelines for exercise testing and prescription. Wolters Kluwer Health/Lippincott Williams \& Wilkins; 2014.

13. Cumming TB, Thrift AG, Collier JM, et al. Very Early Mobilization After Stroke Fast-Tracks Return to Walking. Stroke. 2011;42(1):153-158.

14. Stoller O, de Bruin ED, Knols RH, et al. Effects of cardiovascular exercise early after stroke: systematic review and meta-analysis. BMC neurology. 2012 Jun 22;12:45.

15. Eng JJ, Chu KS, Kim CM, et al. A community-based group exercise program for persons with chronic stroke. Medicine and Science in Sports and Exercise. 200301 Aug;35(8):1271-1278.

16. Kendall BJ, Gothe NP. Effect of Aerobic Exercise Interventions on Mobility among Stroke Patients: A Systematic Review. Am J Phys Med Rehabil. 2016 Mar;95(3):214-24.

17. Quaney BM, Boyd LA, McDowd JM, et al. Aerobic Exercise Improves Cognition and Motor Function Poststroke. Neurorehabilitation and Neural Repair. 2009;23(9):879-885.

18. van Duijnhoven $\mathrm{HJ}$, Heeren A, Peters MA, et al. Effects of Exercise Therapy on Balance Capacity in Chronic Stroke: Systematic Review and Meta-Analysis. Stroke. 2016 Oct;47(10):2603-10.

19. Wang C, Redgrave J, Shafizadeh M, et al. Aerobic exercise interventions reduce blood pressure in patients after stroke or transient ischaemic attack: a systematic review and meta-analysis. Br J Sports Med. 2018 May 9.

20. D'Isabella NT, Shkredova DA, Richardson JA, et al. Effects of exercise on cardiovascular risk factors following stroke or transient ischemic attack: a systematic review and meta-analysis. Clinical Rehabilitation. 2017;31(12):1561-1572.

21. Saunders $D H$, Sanderson $M$, Hayes $S$, et al. Physical fitness training for stroke patients. Cochrane Database Syst Rev. 2016 Mar 24;3:CD003316. 
22. Royal College of Physicians Intercollegiate Stroke Working Party. RCP National clinical guidelines for stroke:: 5th edition. London: Royal College of Physicians; 2016.

23. Winstein CJ, Stein J, Arena R, et al. Guidelines for Adult Stroke Rehabilitation and Recovery. A Guideline for Healthcare Professionals From the American Heart Association/American Stroke Association. 2016.

24. Hebert $D$, Lindsay MP, McIntyre A, et al. Canadian stroke best practice recommendations: Stroke rehabilitation practice guidelines, update 2015. International journal of stroke : official journal of the International Stroke Society. 2016 Jun;11(4):459-84.

25. National Institute for Health and Care Excellence. NICE Pathways: Movement difficulties after a stroke2019 [cited. DOI:https://pathways.nice.org.uk/pathways/stroke/movementdifficulties-after-a-stroke

26. French B, Thomas LH, Coupe J, et al. Repetitive task training for improving functional ability after stroke. Cochrane Database Syst Rev. 2016 Nov 14;11:CD006073.

27. Veerbeek JM, van Wegen $E$, van Peppen $R$, et al. What is the evidence for physical therapy poststroke? A systematic review and meta-analysis. PloS one. 2014;9(2):e87987.

28. Bernhardt J, Dewey H, Thrift A, et al. Inactive and alone physical activity within the first 14 days of acute stroke unit care. Stroke. 2004;35(4):1005-1009.

29. Healthcare Quality Improvement Partnership. Rising to the Challenge: The Fourth Sentinel Stroke National Audit Programme (SSNAP) Annual Report. 2017.

30. Ivey FM, Hafer-Macko CE, Macko RF. Exercise rehabilitation after stroke. NeuroRx. 2006 Oct;3(4):439-50.

31. Boyne P, Welge J, Kissela B, et al. Factors Influencing the Efficacy of Aerobic Exercise for Improving Fitness and Walking Capacity After Stroke: A Meta-Analysis With MetaRegression. Archives of Physical Medicine and Rehabilitation. 2017 2017/03/01/;98(3):581595.

32. Biasin L, Sage MD, Brunton K, et al. Integrating aerobic training within subacute stroke rehabilitation: a feasibility study. Physical therapy. 2014 Dec;94(12):1796-806.

33. Mansfield A, Brooks D, Tang A, et al. Promoting Optimal Physical Exercise for Life (PROPEL): aerobic exercise and self-management early after stroke to increase daily physical activitystudy protocol for a stepped-wedge randomised trial. BMJ open. 2017 Jun 30;7(6):e015843.

34. Barbosa D, Santos CP, Martins M. The Application of Cycling and Cycling Combined with Feedback in the Rehabilitation of Stroke Patients: A Review. Journal of Stroke and Cerebrovascular Diseases. 2015 2015/02/01/;24(2):253-273.

35. Mehrholz J, Thomas S, Elsner B. Treadmill training and body weight support for walking after stroke. Cochrane Database of Systematic Reviews. 2017 (8).

36. Church G, Parker J, Powell L, et al. The effectiveness of group exercise for improving activity and participation in adult stroke survivors: a systematic review. Physiotherapy. 2019 Jan 19.

37. Doyle L, MacKay-Lyons M. Utilization of Aerobic Exercise in Adult Neurological Rehabilitation by Physical Therapists in Canada. Journal of Neurologic Physical Therapy. 2013;37(1):20-26.

38. Boyne $\mathrm{P}$, Billinger $\mathrm{S}$, MacKay-Lyons M, et al. Aerobic Exercise Prescription in Stroke Rehabilitation: A Web-Based Survey of US Physical Therapists. Journal of Neurologic Physical Therapy. 2017;41(2):119-128.

39. Moher D, Liberati A, Tetzlaff J, et al. Preferred Reporting Items for Systematic Reviews and Meta-Analyses: The PRISMA Statement. PLOS Medicine. 2009;6(7):e1000097.

40. Cooke A, Smith D, Booth A. Beyond PICO: the SPIDER tool for qualitative evidence synthesis. Qual Health Res. 2012 Oct;22(10):1435-43.

41. Greenhalgh T, Peacock R. Effectiveness and efficiency of search methods in systematic reviews of complex evidence: audit of primary sources. BMJ. 2005;331(7524):1064.

42. Ouzzani M, Hammady H, Fedorowicz Z, et al. Rayyan-a web and mobile app for systematic reviews [journal article]. Systematic Reviews. 2016 December 05;5(1):210. 
43. Olofsson $\mathrm{H}$, Brolund $\mathrm{A}$, Hellberg $\mathrm{C}$, et al. Can abstract screening workload be reduced using text mining? User experiences of the tool Rayyan. Research Synthesis Methods.

2017;8(3):275-280.

44. Edwards $\mathrm{P}$, Clarke $\mathrm{M}$, DiGuiseppi $\mathrm{C}$, et al. Identification of randomized controlled trials in systematic reviews: accuracy and reliability of screening records. Statistics in medicine. 2002;21(11):1635-1640.

45. Damschroder L, Aron DC, Keith RE, et al. Fostering implementation of health services research findings into practice: a consolidated framework for advancing implementation science. Implement Sci. 2009 Aug 7;4:50.

46. Booth A, Noyes J, Flemming K, et al. Guidance on choosing qualitative evidence synthesis methods for use in health technology assessments of complex interventions. IntegrateHTA2016.

47. Noyes J, Booth A, Flemming K, et al. Cochrane Qualitative and Implementation Methods Group guidance series-paper 3: methods for assessing methodological limitations, data extraction and synthesis, and confidence in synthesized qualitative findings. J Clin Epidemiol. 2018 May;97:49-58.

48. Hannes K. Chapter 4: Critical appraisal of qualitative research. In: Noyes J, Booth A, Hannes K, Harden A, Harris J, Lewin S, Lockwood C (editors), Supplementary Guidance for Inclusion of Qualitative Research in Cochrane Systematic Reviews of Interventions. Version 1 (updated August 2011). 2011.

49. Axelson $\mathrm{M}$, Reimer $\mathrm{E}$, Leung $\mathrm{G}$, et al. Implementation of an aerobic fitness program in inpatient stroke rehabilitation [Conference Abstract]. Stroke. 2014 December;45 (12):e286.

50. Prout EC, Mansfield A, Mcllroy WE, et al. Physiotherapists' perspectives on aerobic exercise early after stroke: A preliminary study. Physiother Theory Pract. 2016 Aug;32(6):452-460.

51. Condon M, Guidon M. A survey of exercise professionals' barriers and facilitators to working with stroke survivors. Health \& Social Care in the Community. 2018;26(2):250-258.

52. Desveaux L, Goldstein R, Mathur S, et al. Barriers to Physical Activity Following Rehabilitation: Perspectives of Older Adults with Chronic Disease. Journal of aging and physical activity. 201601 Apr;24(2):223-233.

53. Salbach NM, Howe JA, Baldry D, et al. Considerations for expanding community exercise programs incorporating a healthcare-recreation partnership for people with balance and mobility limitations: a mixed methods evaluation. BMC research notes. 201802 Apr;11(1):214.

54. Diehl D, Carroll B, Rachael E, et al. Physical therapists' utilization of high intensity interval training in stroke rehab in central Indiana. Cardiopulmonary Physical Therapy Journal. 2017 January;28 (1):37-38.

55. Fullerton A, Macdonald M, Brown A, et al. Survey of fitness facilities for individuals poststroke in the Greater Toronto Area. Applied Physiology, Nutrition and Metabolism. 2008 August;33(4):713-719.

56. Best C, van Wijck F, Dennis J, et al. A survey of community exercise programmes for stroke survivors in Scotland. Health \& social care in the community. 2012;20(4):400-411.

57. Tang A, Closson V, Marzolini S, et al. Cardiac rehabilitation after stroke - Need and opportunity. Journal of cardiopulmonary rehabilitation and prevention. 2009 MayApril;29(2):97-104.

58. Eng XW, Brauer SG, Kuys SS, et al. Facilitators and barriers to people with stroke performing independent therapeutic practice outside therapy time during in-patient stroke rehabilitation [Conference Abstract]. Physiotherapy (United Kingdom). 2015 May;1):eS362es363.

59. Stewart C, Power E, McCluskey A, et al. Barriers and enablers to increasing the amount of practice completed by stroke survivors during inpatient rehabilitation [Conference Abstract]. International Journal of Stroke. 2017 August;12 (2 Supplement 1):14-15. 
60. Zinger D, Maathuis R, Port Van De IGL, et al. Development and use of an exercise-guide for stroke patients [Conference Abstract]. Physiotherapy (United Kingdom). 2011 June;1):eS1632.

61. Miller ET, Dunning K, Whitesel D, et al. Identifying the "new norm" of cardiac rehabilitation after stroke [Conference Abstract]. Stroke Conference: American Heart Association/American Stroke Association. 2017;48(Supplement 1).

62. Ali A, Church G, Bec R, et al. Enhancing uptake of an exercise programme after stroke or transient ischaemic attack (TIA)-a co-production event [Conference Abstract]. International Journal of Stroke. 2018 December;13 (3 Supplement 1):29.

63. Otterman NM, van der Wees PJ, Bernhardt J, et al. Physical Therapists' Guideline Adherence on Early Mobilization and Intensity of Practice at Dutch Acute Stroke Units. Stroke. 2012 September 1, 2012;43(9):2395-2401.

64. Waters L, Kuys SS, Ada L, et al. Physiotherapists' perceptions about implementing treadmill training into inpatient stroke rehabilitation: A qualitative study [Conference Abstract]. International Journal of Stroke. 2014 July;1):7.

65. Wiles R, Demain S, Robison J, et al. Exercise on prescription schemes for stroke patients post-discharge from physiotherapy. Disability and Rehabilitation. 2008;30(26):1966-1975.

66. Clague-Baker NR, T. Drewry, S. Hagenberg, A. Singh, S. . Cardiac rehabilitation and stroke teams attitudes to people with stroke taking part in cardiac rehabilitation: a focus group study.: International Journal of Stroke; 2015.

67. Together in Movement and Exercise (ТIME' ${ }^{\mathrm{TM}}$ ), http://www.uhn.ca/TorontoRehab/PatientsFamilies/Clinics Tests/TIME. 2019 [cited 2019 Accessed 25 September].

68. Charrois TL. Systematic reviews: what do you need to know to get started? Can J Hosp Pharm. 2015 Mar-Apr;68(2):144-148.

69. Yamato TP, Maher CG, Saragiotto BT, et al. How completely are physiotherapy interventions described in reports of randomised trials? Physiotherapy. 2016 2016/06/01/;102(2):121-126.

70. Hoffmann TC, Glasziou PP, Boutron I, et al. Better reporting of interventions: template for intervention description and replication (TIDieR) checklist and guide. BMJ. 2014;348(g1687).

71. Kirk MA, Kelley C, Yankey N, et al. A systematic review of the use of the Consolidated Framework for Implementation Research [journal article]. Implementation Science. 2016 May 17;11(1):72.

72. Kalkan A, Roback $K$, Hallert $E$, et al. Factors influencing rheumatologists' prescription of biological treatment in rheumatoid arthritis: an interview study [journal article]. Implementation Science. 2014 October 11;9(1):153.

73. Ilott I, Gerrish K, Booth A, et al. Testing the Consolidated Framework for Implementation Research on health care innovations from South Yorkshire. J Eval Clin Pract. 2013 Oct;19(5):915-24.

74. Cilenti D, Brownson RC, Umble K, et al. Information-Seeking Behaviors and Other Factors Contributing to Successful Implementation of Evidence-Based Practices in Local Health Departments. Journal of Public Health Management and Practice. 2012;18(6):571-576.

75. Damschroder L, Lowery JC. Evaluation of a large-scale weight management program using the consolidated framework for implementation research (CFIR). Implement Sci. 2013 May 10;8:51.

76. Michie S, Atkins L, West R. The Behaviour Change Wheel: A Guide To Designing Interventions. 2014.

77. Stokke K, Olsen NR, Espehaug B, et al. Evidence based practice beliefs and implementation among nurses: a cross-sectional study. BMC Nursing. 2014 2014/03/25;13(1):8.

78. Van Kessel G, Hillier S, English C. Physiotherapists' attitudes toward circuit class therapy and 7 day per week therapy is influenced by normative beliefs, past experience, and perceived control: A qualitative study. Physiother Theory Pract. 2017 Nov;33(11):850-858. 
79. Bird M-L, Miller T, Connell LA, et al. Moving stroke rehabilitation evidence into practice: a systematic review of randomized controlled trials. Clinical rehabilitation.

2019:0269215519847253.

80. Birken S, Clary A, Tabriz AA, et al. Middle managers' role in implementing evidence-based practices in healthcare: a systematic review [journal article]. Implementation Science. 2018 December 12;13(1):149.

81. Birken SA, Rohweder CL, Powell BJ, et al. T-CaST: an implementation theory comparison and selection tool [journal article]. Implementation Science. 2018 November 22;13(1):143.

82. Birken SA, Powell BJ, Shea CM, et al. Criteria for selecting implementation science theories and frameworks: results from an international survey. Implement Sci. 2017 Oct 30;12(1):124.

83. Lynch EA, Mudge A, Knowles S, et al. "There is nothing so practical as a good theory": a pragmatic guide for selecting theoretical approaches for implementation projects. BMC Health Serv Res. 2018 Nov 14;18(1):857. 
Tables

Table 1: Consolidated Framework for Implementation Research Constructs from The Consolidated

Framework for Implementation Research [internet]. Michigan; 2019. [Cited 04/04/2019]. Available

from: https://cfirguide.org/constructs/

\section{Consolidated Framework for Implementation Research Constructs}

\section{CFIR Website}

\begin{tabular}{|l|l|l|}
\hline \multicolumn{2}{|l|}{ Construct } & Short Description \\
\hline I. INTERVENTION CHARACTERISTICS & Intervention Source & $\begin{array}{l}\text { Perception of key stakeholders about whether the intervention is } \\
\text { externally or internally developed. }\end{array}$ \\
\hline B & Evidence Strength \& Quality & $\begin{array}{l}\text { Stakeholders' perceptions of the quality and validity of evidence } \\
\text { supporting the belief that the intervention will have desired outcomes. }\end{array}$ \\
\hline C & Relative Advantage & $\begin{array}{l}\text { Stakeholders' perception of the advantage of implementing the } \\
\text { intervention versus an alternative solution. }\end{array}$ \\
\hline D & Adaptability & $\begin{array}{l}\text { The degree to which an intervention can be adapted, tailored, refined, } \\
\text { or reinvented to meet local needs. }\end{array}$ \\
\hline E & Trialability & $\begin{array}{l}\text { The ability to test the intervention on a small scale in the organization, } \\
\text { and to be able to reverse course (undo implementation) if warranted. }\end{array}$ \\
\hline F & Complexity & $\begin{array}{l}\text { Perceived difficulty of implementation, reflected by duration, scope, } \\
\text { radicalness, disruptiveness, centrality, and intricacy and number of } \\
\text { steps required to implement. }\end{array}$ \\
\hline A & Patient Needs \& Resources & $\begin{array}{l}\text { Perceived excellence in how the intervention is bundled, presented, } \\
\text { and assembled. }\end{array}$ \\
\hline H & Cost & $\begin{array}{l}\text { Costs of the intervention and costs associated with implementing the } \\
\text { intervention including investment, supply, and opportunity costs. } \\
\text { organization. }\end{array}$ \\
\hline II. OUTER SETTING & Desich patient needs, as well as barriers and facilitators to \\
\hline
\end{tabular}




\begin{tabular}{|c|c|c|}
\hline B & Cosmopolitanism & $\begin{array}{l}\text { The degree to which an organization is networked with other external } \\
\text { organizations. }\end{array}$ \\
\hline $\mathrm{C}$ & Peer Pressure & $\begin{array}{l}\text { Mimetic or competitive pressure to implement an intervention; } \\
\text { typically because most or other key peer or competing organizations } \\
\text { have already implemented or are in a bid for a competitive edge. }\end{array}$ \\
\hline $\mathrm{D}$ & External Policy \& Incentives & $\begin{array}{l}\text { A broad construct that includes external strategies to spread } \\
\text { interventions, including policy and regulations (governmental or other } \\
\text { central entity), external mandates, recommendations and guidelines, } \\
\text { pay-for-performance, collaboratives, and public or benchmark } \\
\text { reporting. }\end{array}$ \\
\hline \multicolumn{3}{|c|}{ III. INNER SETTING } \\
\hline A & Structural Characteristics & The social architecture, age, maturity, and size of an organization. \\
\hline B & Networks \& Communications & $\begin{array}{l}\text { The nature and quality of webs of social networks and the nature and } \\
\text { quality of formal and informal communications within an organization. }\end{array}$ \\
\hline $\mathrm{C}$ & Culture & Norms, values, and basic assumptions of a given organization. \\
\hline $\mathrm{D}$ & Implementation Climate & $\begin{array}{l}\text { The absorptive capacity for change, shared receptivity of involved } \\
\text { individuals to an intervention, and the extent to which use of that } \\
\text { intervention will be rewarded, supported, and expected within their } \\
\text { organization. }\end{array}$ \\
\hline 1 & Tension for Change & $\begin{array}{l}\text { The degree to which stakeholders perceive the current situation as } \\
\text { intolerable or needing change. }\end{array}$ \\
\hline 2 & Compatibility & $\begin{array}{l}\text { The degree of tangible fit between meaning and values attached to the } \\
\text { intervention by involved individuals, how those align with individuals' } \\
\text { own norms, values, and perceived risks and needs, and how the } \\
\text { intervention fits with existing workflows and systems. }\end{array}$ \\
\hline 3 & Relative Priority & $\begin{array}{l}\text { Individuals' shared perception of the importance of the } \\
\text { implementation within the organization. }\end{array}$ \\
\hline 4 & $\begin{array}{l}\text { Organizational Incentives \& } \\
\text { Rewards }\end{array}$ & $\begin{array}{l}\text { Extrinsic incentives such as goal-sharing awards, performance reviews, } \\
\text { promotions, and raises in salary, and less tangible incentives such as } \\
\text { increased stature or respect. }\end{array}$ \\
\hline 5 & Goals and Feedback & $\begin{array}{l}\text { The degree to which goals are clearly communicated, acted upon, and } \\
\text { fed back to staff, and alignment of that feedback with goals. }\end{array}$ \\
\hline 6 & Learning Climate & $\begin{array}{l}\text { A climate in which: a) leaders express their own fallibility and need for } \\
\text { team members' assistance and input; b) team members feel that they } \\
\text { are essential, valued, and knowledgeable partners in the change } \\
\text { process; c) individuals feel psychologically safe to try new methods; } \\
\text { and d) there is sufficient time and space for reflective thinking and } \\
\text { evaluation. }\end{array}$ \\
\hline
\end{tabular}




\begin{tabular}{|c|c|c|}
\hline $\mathrm{E}$ & Readiness for Implementation & $\begin{array}{l}\text { Tangible and immediate indicators of organizational commitment to its } \\
\text { decision to implement an intervention. }\end{array}$ \\
\hline 1 & Leadership Engagement & $\begin{array}{l}\text { Commitment, involvement, and accountability of leaders and } \\
\text { managers with the implementation. }\end{array}$ \\
\hline 2 & Available Resources & $\begin{array}{l}\text { The level of resources dedicated for implementation and on-going } \\
\text { operations, including money, training, education, physical space, and } \\
\text { time. }\end{array}$ \\
\hline 3 & $\begin{array}{l}\text { Access to Knowledge \& } \\
\text { Information }\end{array}$ & $\begin{array}{l}\text { Ease of access to digestible information and knowledge about the } \\
\text { intervention and how to incorporate it into work tasks. }\end{array}$ \\
\hline \multicolumn{3}{|c|}{ IV. CHARACTERISTICS OF INDIVIDUALS } \\
\hline A & $\begin{array}{l}\text { Knowledge \& Beliefs about the } \\
\text { Intervention }\end{array}$ & $\begin{array}{l}\text { Individuals' attitudes toward and value placed on the intervention as } \\
\text { well as familiarity with facts, truths, and principles related to the } \\
\text { intervention. }\end{array}$ \\
\hline B & Self-efficacy & $\begin{array}{l}\text { Individual belief in their own capabilities to execute courses of action } \\
\text { to achieve implementation goals. }\end{array}$ \\
\hline $\mathrm{C}$ & Individual Stage of Change & $\begin{array}{l}\text { Characterization of the phase an individual is in, as he or she } \\
\text { progresses toward skilled, enthusiastic, and sustained use of the } \\
\text { intervention. }\end{array}$ \\
\hline $\mathrm{D}$ & $\begin{array}{l}\text { Individual Identification with } \\
\text { Organization }\end{array}$ & $\begin{array}{l}\text { A broad construct related to how individuals perceive the organization, } \\
\text { and their relationship and degree of commitment with that } \\
\text { organization. }\end{array}$ \\
\hline$E$ & Other Personal Attributes & $\begin{array}{l}\text { A broad construct to include other personal traits such as tolerance of } \\
\text { ambiguity, intellectual ability, motivation, values, competence, } \\
\text { capacity, and learning style. }\end{array}$ \\
\hline \multicolumn{3}{|c|}{ V. PROCESS } \\
\hline A & Planning & $\begin{array}{l}\text { The degree to which a scheme or method of behavior and tasks for } \\
\text { implementing an intervention are developed in advance, and the } \\
\text { quality of those schemes or methods. }\end{array}$ \\
\hline$B$ & Engaging & $\begin{array}{l}\text { Attracting and involving appropriate individuals in the implementation } \\
\text { and use of the intervention through a combined strategy of social } \\
\text { marketing, education, role modeling, training, and other similar } \\
\text { activities. }\end{array}$ \\
\hline 1 & Opinion Leaders & $\begin{array}{l}\text { Individuals in an organization who have formal or informal influence on } \\
\text { the attitudes and beliefs of their colleagues with respect to } \\
\text { implementing the intervention. }\end{array}$ \\
\hline 2 & $\begin{array}{l}\text { Formally Appointed Internal } \\
\text { Implementation Leaders }\end{array}$ & $\begin{array}{l}\text { Individuals from within the organization who have been formally } \\
\text { appointed with responsibility for implementing an intervention as } \\
\text { coordinator, project manager, team leader, or other similar role. }\end{array}$ \\
\hline
\end{tabular}




\begin{tabular}{|l|l|l|}
\hline 3 & Champions & $\begin{array}{l}\text { "Individuals who dedicate themselves to supporting, marketing, and } \\
\text { 'driving through' an [implementation]" [101] (p. 182), overcoming } \\
\text { indifference or resistance that the intervention may provoke in an } \\
\text { organization. }\end{array}$ \\
\hline 4 & External Change Agents & $\begin{array}{l}\text { Individuals who are affiliated with an outside entity who formally } \\
\text { influence or facilitate intervention decisions in a desirable direction. }\end{array}$ \\
\hline C & Executing & Carrying out or accomplishing the implementation according to plan. \\
\hline D & Reflecting \& Evaluating & $\begin{array}{l}\text { Quantitative and qualitative feedback about the progress and quality } \\
\text { of implementation accompanied with regular personal and team } \\
\text { debriefing about progress and experience. }\end{array}$ \\
\hline
\end{tabular}


Table 2: Summary of Included Studies

\begin{tabular}{|c|c|c|c|c|c|}
\hline $\begin{array}{l}\text { Author, year, } \\
\text { country }\end{array}$ & Design & Setting & $\begin{array}{l}\text { Population \& Participant } \\
\text { Characteristics }\end{array}$ & Methods & Results \\
\hline $\begin{array}{l}\text { *Ali et al, } 2018 \\
\text { [62]; United } \\
\text { Kingdom }\end{array}$ & Workshops & Not reported & $\begin{array}{l}\text { 30-40 stakeholders } \\
\text { including stroke survivors, } \\
\text { carers, therapists, exercise } \\
\text { professionals, doctors, } \\
\text { social services, } \\
\text { commissioners, the } \\
\text { voluntary and private } \\
\text { sector. }\end{array}$ & $\begin{array}{l}\text { Double diamond } \\
\text { approach for } 2 \\
\text { workshops co-facilitated } \\
\text { by a multidisciplinary } \\
\text { team and } 2 \text { designers } \\
\text { aiming to promote } \\
\text { exercise post-stroke. } \\
\text { Data analysed } \\
\text { thematically. }\end{array}$ & $\begin{array}{l}\text { Key themes identified: } \\
\text { - a variation in information } \\
\text { exchange amongst patients \& } \\
\text { clinicians } \\
\text { - a need to integrate exercise \& } \\
\text { rehabilitation and for support to } \\
\text { access services } \\
3 \text { main barriers: } \\
\text { - Lack of access to information, } \\
\text { accessibility and infrastructure }\end{array}$ \\
\hline $\begin{array}{l}\text { *Axelson et al, } \\
2014 \text { [49]; Canada }\end{array}$ & $\begin{array}{l}\text { Development and } \\
\text { implementation } \\
\text { of aerobic fitness } \\
\text { programme in } \\
\text { sub-acute post- } \\
\text { stroke } \\
\text { rehabilitation } \\
\text { guided by a } \\
\text { literature review. }\end{array}$ & $\begin{array}{l}\text { Neuro- } \\
\text { Rehabilitation } \\
\text { Unit }\end{array}$ & $\begin{array}{l}\text { People post-stroke and } \\
\text { clinicians delivering aerobic } \\
\text { exercise to this population. } \\
\text { Number of participants not } \\
\text { stated }\end{array}$ & $\begin{array}{l}\text { Development of an } \\
\text { Aerobic Fitness } \\
\text { Programme for } \\
\text { subacute post-stroke } \\
\text { rehabilitation guided by } \\
\text { a literature review and } \\
\text { based on 'The Aerobic } \\
\text { Exercise } \\
\text { Recommendations to } \\
\text { Optimize Best Practices } \\
\text { Care after Stroke' }\end{array}$ & $\begin{array}{l}\text { Challenges: } \\
\text { Patients' cognitive \& physical } \\
\text { abilities, comorbidities } \\
\text { - exercise testing and intensity } \\
\text { monitoring } \\
\text { - incorporation into schedules }\end{array}$ \\
\hline
\end{tabular}




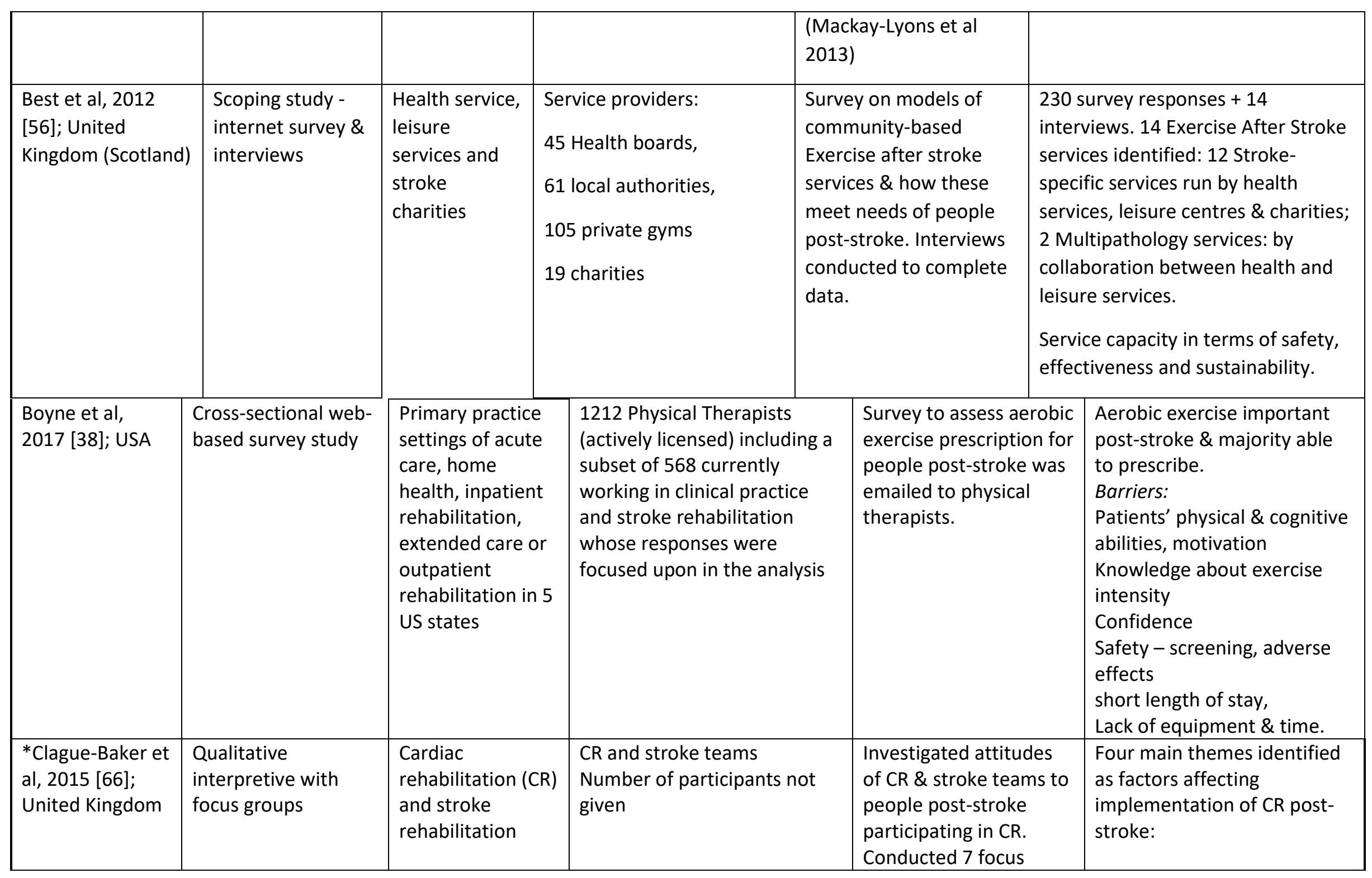




\begin{tabular}{|c|c|c|c|c|c|}
\hline & & & & $\begin{array}{l}\text { groups prior to stroke } \\
\text { patients participating in } \\
\text { CR \& } 5 \text { focus groups } \\
\text { after participation. Data } \\
\text { analysed thematically. }\end{array}$ & $\begin{array}{l}\text { 1) Confidence in delivering } \\
\text { the service } \\
\text { 2) Stroke and exercise } \\
\text { 3) Lack of knowledge } \\
\text { 4) Cardiac adaptations }\end{array}$ \\
\hline $\begin{array}{l}\text { Condon and } \\
\text { Guidon, } 2018 \\
\text { [51] ; Ireland }\end{array}$ & $\begin{array}{l}\text { Cross-sectional } \\
\text { descriptive study } \\
\text { using an online } \\
\text { survey. }\end{array}$ & $\begin{array}{l}\text { Community - } \\
\text { various }\end{array}$ & $\begin{array}{l}87 \text { Exercise Professionals } \\
\text { (EPs) ( } 31 \% \text { response rate) } \\
\text { registered with the Register } \\
\text { of Exercise Professionals } \\
\text { (REPs) in Ireland. } \\
\text { Median of } 5 \text { years' } \\
\text { experience, } n=19 \text { had } \\
\text { experience with people post- } \\
\text { stroke. } \\
40 \% \text { based in gyms, } 36 \% \text { in } \\
\text { for-profit exercise facilities. } \\
25 \% \text { received training on } \\
\text { stroke as part of EP training } \\
\text { with } 17 \% \text { completing CPD on } \\
\text { stroke post-qualification. }\end{array}$ & $\begin{array}{l}\text { Researcher-designed } \\
\text { survey used to } \\
\text { investigate the opinions } \\
\text { of EPs on working with } \\
\text { people post-stroke. This } \\
\text { included rating barriers } \\
\text { and facilitators, } \\
\text { quantifying experience } \\
\text { \& skills and exploring } \\
\text { how training related to } \\
\text { the barriers and } \\
\text { facilitators. Survey link } \\
\text { emailed to eligible REPS } \\
\text { members by REPs. } \\
\text { Calculation of } \\
\text { descriptive statistics } \\
\text { using IBM SPSS } 22.0 \text {. }\end{array}$ & $\begin{array}{l}\text { Most were interested in } \\
\text { working with people post- } \\
\text { stroke. } \\
\text { Barriers: } \\
\text { - training, equipment, safety } \\
\text { and cost of staffing } \\
\text { Facilitators: } \\
\text { - training, professional } \\
\text { certification and funding for } \\
\text { this, } \\
\text { - equipment, environment, } \\
\text { - liaison between } \\
\text { physiotherapists and EPs. }\end{array}$ \\
\hline $\begin{array}{l}\text { Desveaux et al, } \\
2016 \text { [52]; } \\
\text { Canada }\end{array}$ & $\begin{array}{l}\text { Quantitative study } \\
\text { using a cross- } \\
\text { sectional design } \\
\text { using a patient- } \\
\text { barriers } \\
\text { questionnaire }\end{array}$ & $\begin{array}{l}\text { Hospital-based } \\
\text { rehabilitation } \\
\text { facilities }\end{array}$ & $\begin{array}{l}35 \text { health care professionals } \\
\text { (HCPs): } \\
19 \text { physiotherapists } \\
10 \text { kinesiologists } \\
6 \text { physicians } \\
83 \text { patients with } \\
\text { multimorbidities including } \\
\text { stroke }\end{array}$ & $\begin{array}{l}\text { Barriers to physical } \\
\text { activity post- } \\
\text { rehabilitation explored } \\
\text { via modified version of } \\
\text { the Cardiac } \\
\text { Rehabilitation Barriers } \\
\text { Scale (CRBS) completed } \\
\text { by patients with heart } \\
\text { failure, stroke, diabetes } \\
\& \text { COPD and by HCPs }\end{array}$ & $\begin{array}{l}\text { Barriers perceived by HCPs: } \\
\text { Travel time } \\
\text { lack of motivation } \\
\text { cost } \\
\text { severity of symptoms } \\
\text { Facilitators: } \\
\text { Referral from HCP } \\
\text { Facilitated transition to the } \\
\text { programme. }\end{array}$ \\
\hline
\end{tabular}




\begin{tabular}{|c|c|c|c|c|c|}
\hline & & & & $\begin{array}{l}\text { working with these } \\
\text { populations. } \\
\text { Questionnaires } \\
\text { delivered via 1:1 } \\
\text { interviews, face-to-face } \\
\text { apart from } 5 \text { via phone. } \\
\text { Perceived barriers to } \\
\text { participation in } \\
\text { community-based } \\
\text { exercise were evaluated } \\
\text { quantitively. }\end{array}$ & $\begin{array}{l}\text { Suggested solutions: } \\
\text { Reduced rehabilitation-to- } \\
\text { community transition time. } \\
\text { Transportation strategy } \\
\text { Accessible and supportive } \\
\text { community environment. }\end{array}$ \\
\hline $\begin{array}{l}\text { *Diehl et al, } \\
2017 \text { [54]; USA }\end{array}$ & $\begin{array}{l}\text { Pilot, non- } \\
\text { experimental } \\
\text { descriptive study } \\
\text { using anonymous } \\
\text { surveys }\end{array}$ & $\begin{array}{l}\text { Healthcare, exact } \\
\text { setting not given }\end{array}$ & $\begin{array}{l}31 \text { Indiana-based physical } \\
\text { therapists with } 50 \% \text { practice } \\
\text { time spent with people with } \\
\text { sub-acute CVA }\end{array}$ & $\begin{array}{l}\text { To explore the } \\
\text { familiarity with and } \\
\text { understanding of the } \\
\text { use of high intensity } \\
\text { interval training (HIIT) } \\
\text { in CVA rehabilitation } \\
\text { and barriers to } \\
\text { implementation of HIIT }\end{array}$ & $\begin{array}{l}\text { 16.1\% reported using HIIT in } \\
\text { practice } \\
\text { Barriers: } \\
\text { - } 51.8 \% \text { inadequate } \\
\text { understanding of HIIT } \\
\text { - } 48.1 \% \text { patient comorbidities } \\
-77.8 \% \text { unable to perform } \\
\text { exercise testing } \\
\text { - } 48.1 \% \text { lack of access to } \\
\text { support personnel }\end{array}$ \\
\hline $\begin{array}{l}\text { Doyle et al, } 2013 \\
\text { [37]; Canada }\end{array}$ & $\begin{array}{l}\text { Quantitative cross- } \\
\text { sectional web-based } \\
\text { survey study }\end{array}$ & $\begin{array}{l}\text { Rehabilitation } \\
\text { centres, } \\
\text { Public/private } \\
\text { outpatient clinic, } \\
\text { Community/home } \\
\text { Stroke unit, } \\
\text { General hospital } \\
\text { ward }\end{array}$ & $\begin{array}{l}155 \text { Physical therapists } \\
\text { practicing adult } \\
\text { neurorehabilitation } \\
\text { (Response rate } 36 \% \text { ) }\end{array}$ & $\begin{array}{l}\text { Electronically } \\
\text { distributed Survey } \\
\text { regarding use of aerobic } \\
\text { exercise (AEx) in clinical } \\
\text { practice for } \\
\text { neurological } \\
\text { populations including } \\
\text { stroke. } \\
\text { Closed questions } \\
\text { (profile, screening, }\end{array}$ & $\begin{array}{l}\text { Most agreed AEx should be } \\
\text { part of treatment programs } \\
\text { for neurological population \& } \\
\text { prescribed AEx in their } \\
\text { practice. } \\
\text { Barriers: } \\
\text { - safety, patients' inability to } \\
\text { participate } \\
\text { - resources (staffing, training, } \\
\text { screening tools, knowledge), }\end{array}$ \\
\hline
\end{tabular}




\begin{tabular}{|c|c|c|c|c|c|}
\hline & & & & $\begin{array}{l}\text { prescription and } \\
\text { implementation } \mathrm{AEx} \text { ) }\end{array}$ & $\begin{array}{l}\text {-role of AEx in } \\
\text { neurorehabilitation. } \\
\text { - lack of availability of } \\
\text { exercise stress test but few } \\
\text { said test was essential for } \\
\text { safety }\end{array}$ \\
\hline $\begin{array}{l}\text { *Eng et al, } 2015 \\
\text { [58]; Australia }\end{array}$ & $\begin{array}{l}\text { Pilot study - 1:1 } \\
\text { interviews and focus } \\
\text { groups }\end{array}$ & $\begin{array}{l}\text { Tertiary } \\
\text { metropolitan } \\
\text { hospital }\end{array}$ & $\begin{array}{l}20 \text { Clinical staff (professions } \\
\text { not stated) } \\
7 \text { People post-stroke who } \\
\text { were inpatients } \\
6 \text { main carers }\end{array}$ & $\begin{array}{l}\text { Explored factors } \\
\text { affecting people post- } \\
\text { stroke performing } \\
\text { inpatient independent } \\
\text { therapeutic practice } \\
\text { outside therapy time. } \\
\text { Interviews with people } \\
\text { post-stroke \& their } \\
\text { main carer. } 2 \text { focus } \\
\text { groups with clinical } \\
\text { staff. Data analysed } \\
\text { thematically. }\end{array}$ & $\begin{array}{l}\text { Barriers: } \\
\text { Majority of time outside } \\
\text { therapy spent dealing with } \\
\text { loss caused by stroke. } \\
\text { Differences in patient and } \\
\text { staff perceptions of key } \\
\text { motivation for rehabilitation. } \\
\text { Facilitators: } \\
\text { - accessible exercise } \\
\text { equipment, } \\
\text { - private space for structured } \\
\text { therapy homework, } \\
\text { - simulated real world } \\
\text { engagement }\end{array}$ \\
\hline $\begin{array}{l}\text { Fullerton et al, } \\
2008 \text { [55]; } \\
\text { Canada }\end{array}$ & $\begin{array}{l}\text { Descriptive cross- } \\
\text { sectional study with } \\
\text { survey/questionnaire }\end{array}$ & $\begin{array}{l}\text { Fitness facilities } \\
\text { (community- } \\
\text { based) in Greater } \\
\text { Toronto Area }\end{array}$ & $\begin{array}{l}213 \text { analysed after exclusions. } \\
\text { Of the } 213,105 \text { were from } \\
\text { for-profit organizations, } \\
56 \text { from government- } \\
\text { sponsored agencies, } \\
44 \text { from non-profit and } \\
8 \text { did not identify funding } \\
\text { model. } \\
\text { Range of health care } \\
\text { professionals employed }\end{array}$ & $\begin{array}{l}\text { Exploration of } \\
\text { characteristics \& } \\
\text { availability of fitness } \\
\text { programs for people } \\
\text { post-stroke via } \\
\text { questionnaire with } 5 \\
\text { subcategories: facilities' } \\
\text { background, program } \\
\text { availability and barriers, } \\
\text { characteristics, physical } \\
\text { and educational } \\
\text { components \& demand }\end{array}$ & $\begin{array}{l}\text { Response rate } 42 \% \text {. } \\
\text { Of the } 213 \text { facilities, } 62 \text { had } \\
\text { specific programmes for } \\
\text { people with chronic } \\
\text { disabilities and of these, } 26 \\
\text { had fitness programmes for } \\
\text { people post-stroke. } \\
\text { Facilities with stroke-specific } \\
\text { progs only: } \\
\text { All delivered aerobic exercise }\end{array}$ \\
\hline
\end{tabular}




\begin{tabular}{|c|c|c|c|c|c|}
\hline & & & & $\begin{array}{l}\text { for fitness programmes } \\
\text { for people after stroke. } \\
\text { Completed by staff } \\
\text { member most qualified } \\
\text { to answer. } \\
\text { Excluded facilities with } \\
\text { mainly cardiac } \\
\text { rehabilitation or } \\
\text { hospital outpatient } \\
\text { rehabilitation (different } \\
\text { to community-based } \\
\text { fitness facilities); home- } \\
\text { exercise program } \\
\text { provision only: } \\
\text { education-only } \\
\text { programs } \\
\text { specialising in a specific } \\
\text { skill, eg, dance or Tae } \\
\text { Kwon Do. }\end{array}$ & $\begin{array}{l}\text { 85\% had specific acceptance } \\
\text { criteria, } \\
35 \% \text { were fixed lengths with } \\
\text { 1:7 instructor-client ratio. } \\
\text { Barriers to implementation of } \\
\text { stroke-specific programmes: } \\
\text { - cost, lack of qualified staff \& } \\
\text { time. } \\
\text { Facilities without stroke- } \\
\text { specific programmes: } \\
\text { Barriers to offering stroke- } \\
\text { specific programmes were } \\
\text { - lack of qualified staff, } \\
\text { - low demand \& cost }\end{array}$ \\
\hline $\begin{array}{l}\text { *Miller et al, } \\
2017 \text { [61]; USA }\end{array}$ & $\begin{array}{l}\text { Explorative } \\
\text { qualitative study - } \\
\text { focus groups and } \\
\text { interviews }\end{array}$ & $\begin{array}{l}\text { Healthcare- } \\
\text { setting not } \\
\text { specified }\end{array}$ & $\begin{array}{l}\text { Stroke survivors, caregivers, } \\
\text { rehabilitation clinicians, nurse } \\
\text { practitioners and physicians. } \\
\text { Number of participants not } \\
\text { given. }\end{array}$ & $\begin{array}{l}\text { Development of a } \\
\text { stroke-specific cardiac } \\
\text { rehabilitation } \\
\text { programme using } \\
\text { stakeholder input via } \\
\text { separate focus groups } \\
\text { with stroke survivors, } \\
\text { caregivers, } \\
\text { rehabilitation clinicians, } \\
\text { nurse practitioners and } \\
\text { interviews with } \\
\text { physicians. }\end{array}$ & $\begin{array}{l}4 \text { main themes: } \\
\text { - safety } \\
\text { - individual prescription of } \\
\text { programme } \\
\text { - return to function \& } \\
\text { maximise potential } \\
\text { - long-term maintenance of } \\
\text { activity } \\
\text { Main components: } \\
\text { - individualised education for } \\
\text { SSs } \\
\text { - exercise testing pre-exercise }\end{array}$ \\
\hline
\end{tabular}




\begin{tabular}{|c|c|c|c|c|c|}
\hline & & & & $\begin{array}{l}\text { Analysis of resulting } \\
\text { themes, patterns and } \\
\text { issues. }\end{array}$ & $\begin{array}{l}\text { - timely implementation } \\
\text { (needs, resources, benefits), } \\
\text { individualisation } \\
\text { - staff training/education } \\
\text { - interdisciplinary approach } \\
\text { - onward referral to } \\
\text { community/home } \\
\text { programmes }\end{array}$ \\
\hline $\begin{array}{l}\text { Otterman et al, } \\
2012 \text { [63]; } \\
\text { Netherlands }\end{array}$ & $\begin{array}{l}\text { Descriptive survey } \\
\text { using web-based } \\
\text { questionnaire }\end{array}$ & $\begin{array}{l}\text { Hospitals with } \\
\text { inpatient } \\
\text { neurological } \\
\text { department }\end{array}$ & $\begin{array}{l}91 \text { Physiotherapists practicing } \\
\text { in acute stroke rehabilitation }\end{array}$ & $\begin{array}{l}\text { 4-part web-based } \\
\text { survey used to examine } \\
\text { physiotherapists' } \\
\text { current practice and } \\
\text { adherence to clinical } \\
\text { practice guidelines for } \\
\text { patients with stroke at } \\
\text { acute hospital stroke } \\
\text { units, the } 4^{\text {th }} \text { part of } \\
\text { which had questions } \\
\text { regarding the barriers } \\
\text { and facilitators for start } \\
\text { of mobilisation and } \\
\text { time dedicated to } \\
\text { exercise therapy. }\end{array}$ & $\begin{array}{l}95 \% \text { response rate } \\
\text { Barriers to adherence to } \\
\text { guidelines: - time, } \\
\text { cooperation by colleagues, } \\
\text { professional characteristics, } \\
\text { flexibility, applicability and } \\
\text { belief. } \\
\text { Barriers for early } \\
\text { mobilisation and exercise } \\
\text { therapy were mainly } \\
\text { patients' health status and } \\
\text { policy \& funding of the } \\
\text { organisation. }\end{array}$ \\
\hline $\begin{array}{l}\text { Prout et al, } 2016 \\
\text { [50]; Canada }\end{array}$ & $\begin{array}{l}\text { Prospective cross- } \\
\text { sectional study with } \\
\text { survey and literature } \\
\text { review }\end{array}$ & $\begin{array}{l}\text { Three Hospital- } \\
\text { based } \\
\text { rehabilitation } \\
\text { centres - with } \\
\text { and without } \\
\text { structured AEx } \\
\text { programme as } \\
\text { part of inpatient } \\
\text { stroke rehab }\end{array}$ & $\begin{array}{l}16 \text { Physiotherapists actively } \\
\text { practising in inpatient acute } \\
\text { stroke rehabilitation }\end{array}$ & $\begin{array}{l}\text { A questionnaire to } \\
\text { identify } \\
\text { physiotherapists' } \\
\text { perceptions of people } \\
\text { post-stroke, the } \\
\text { practice environment } \\
\text { and training on aerobic } \\
\text { exercise post-stroke } \\
\text { was administered via } \\
\text { face-to-face interview }\end{array}$ & $\begin{array}{l}\text { Most agreed aerobic exercise } \\
\text { is essential part of inpatient } \\
\text { stroke rehabilitation. } \\
\text { All willing to upskill to } \\
\text { incorporate aerobic exercise } \\
\text { into their practice. } \\
\text { Site with aerobic exercise } \\
\text { programme had more } \\
\text { equipment available for }\end{array}$ \\
\hline
\end{tabular}




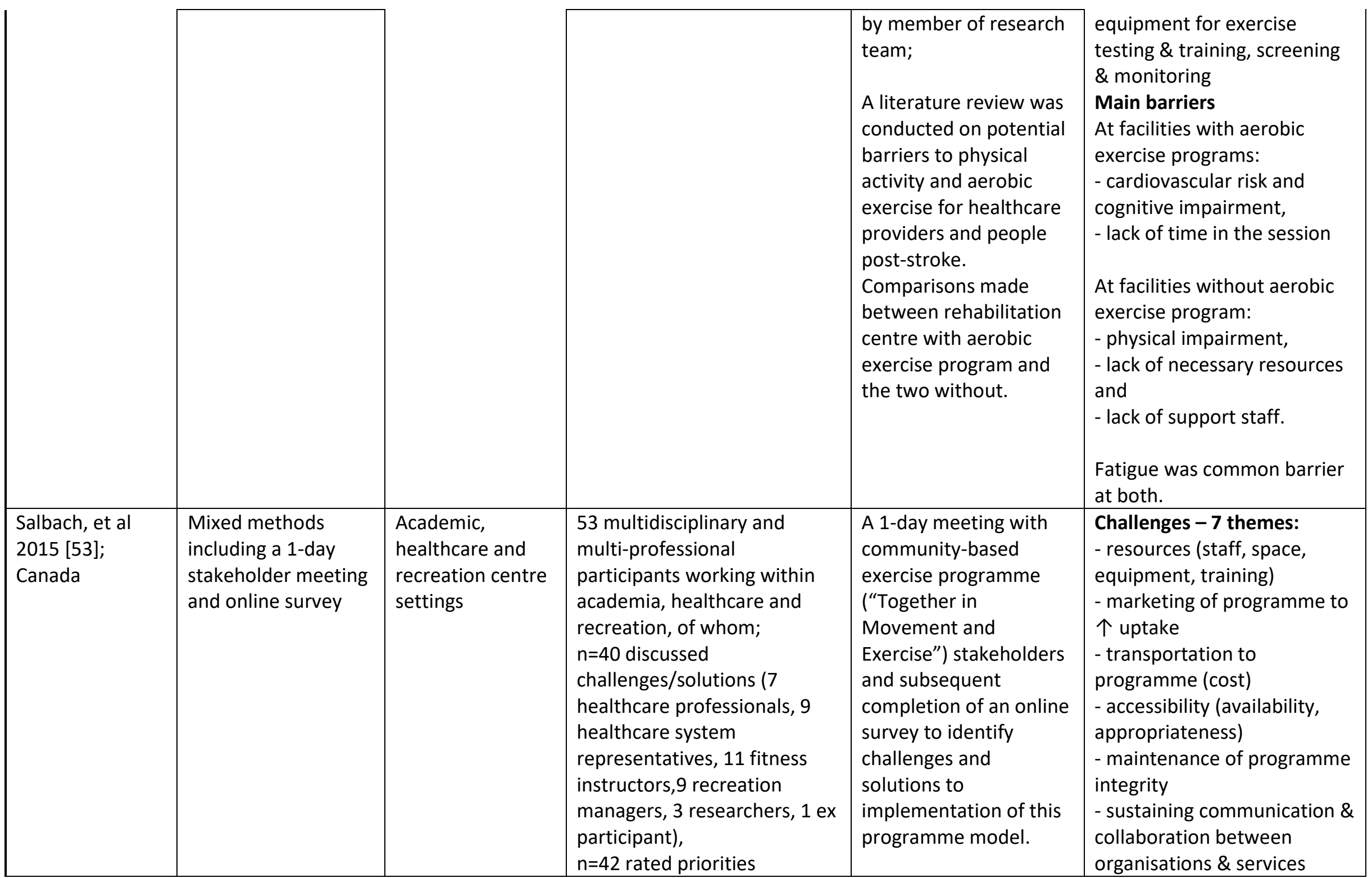




\begin{tabular}{|c|c|c|c|c|c|}
\hline & & & $\begin{array}{l}\mathrm{n}=17 \text { completed online } \\
\text { questionnaire }\end{array}$ & & $\begin{array}{l}\text { - Funding (staff, equipment, } \\
\text { training) }\end{array}$ \\
\hline $\begin{array}{l}\text { *Stewart et al } \\
2017 \text { [59]; } \\
\text { Australia }\end{array}$ & $\begin{array}{l}\text { Qualitative- focus } \\
\text { groups }\end{array}$ & $\begin{array}{l}\text { Rehabilitation } \\
\text { unit }\end{array}$ & $\begin{array}{l}\text { Multidisciplinary: } \\
11 \text { nurses } \\
8 \text { AHPs } \\
2 \text { medical staff }\end{array}$ & $\begin{array}{l}5 \text { multidisciplinary focus } \\
\text { groups conducted to } \\
\text { explore factors } \\
\text { influencing } \\
\text { implementation of } \\
\text { practice books \& nurse- } \\
\text { led weekend classes } \\
\text { which aimed to } \\
\text { increase practice by } \\
\text { inpatient stroke } \\
\text { patients. } \\
\text { Analysed using } \\
\text { framework analysis and } \\
\text { the Theoretical } \\
\text { Domains Framework. } \\
\text { Barriers mapped to } \\
\text { behaviour change } \\
\text { interventions using } \\
\text { Behaviour Change } \\
\text { Wheel framework. }\end{array}$ & $\begin{array}{l}\text { Barriers: } \\
\text { - staff beliefs about patient } \\
\text { motivation to participate in } \\
\text { rehabilitation, } \\
\text { - ward environment } \\
\text { - resources } \\
\text { - ability of staff to motivate \& } \\
\text { supervise active practice. }\end{array}$ \\
\hline $\begin{array}{l}\text { Tang et al, } 2009 \\
\text { [57]; Canada }\end{array}$ & $\begin{array}{l}\text { Survey via email, } \\
\text { phone, fax or post. } \\
\text { Retrospective } \\
\text { database review. }\end{array}$ & $\begin{array}{l}\text { Cardiac } \\
\text { Rehabilitation } \\
\text { programmes' } \\
\text { facilities }\end{array}$ & $\begin{array}{l}40 \text { Cardiac rehabilitation (CR) } \\
\text { programmes }\end{array}$ & $\begin{array}{l}\text { Two-part study to } \\
\text { identify the potential } \\
\text { opportunity and } \\
\text { effectiveness of CR for } \\
\text { people post-stroke } \\
\text { using: } \\
\text { 1) Questionnaire/survey } \\
\text { containing multiple } \\
\text { choice questions (on }\end{array}$ & $\begin{array}{l}40 \text { responses analysed } \\
\text { - } 24 \text { accepting people post- } \\
\text { stroke. } \\
\text { - of these } 14 \text { had no specific } \\
\text { stroke-related restrictions to } \\
\text { program eligibility. } \\
\text { - remaining } 10 \text { facilities } \\
\text { accepted people with } 2^{\circ} \\
\text { diagnosis of stroke and/or }\end{array}$ \\
\hline
\end{tabular}




\begin{tabular}{|c|c|c|c|c|c|}
\hline & & & & $\begin{array}{l}\text { programme use) and } \\
\text { open-ended questions } \\
\text { (barriers to enrolment) } \\
\text { 2) Retrospective } \\
\text { database review to } \\
\text { compare effects of } \mathrm{CR} \\
\text { for people with } 1^{\circ} \\
\text { diagnoses of TIA/stroke } \\
\text { with those with } 2^{\circ} \\
\text { diagnosis TIA/stroke } \\
\text { with those cardiac } \\
\text { diagnoses only }\end{array}$ & $\begin{array}{l}\text { those with mild or moderate } \\
\text { impairments only. } \\
\text { Reasons for exclusion from } \\
\text { programs: - impaired } \\
\text { walking } \\
\text { - cognitive or communication } \\
\text { ability. } \\
\text { Some adaptation to } \\
\text { accommodate people post- } \\
\text { stroke (equipment, staffing, } \\
\text { individual exercise } \\
\text { prescription) provided by } 16 \\
\text { facilities }\end{array}$ \\
\hline $\begin{array}{l}\text { *Waters et al } \\
2014[64] \\
\text { Australia }\end{array}$ & $\begin{array}{l}\text { Qualitative study. } \\
\text { Semi-structured } \\
\text { interviews and focus } \\
\text { groups }\end{array}$ & $\begin{array}{l}\text { Rehabilitation } \\
\text { facilities - one } \\
\text { rehabilitation and } \\
\text { one acute care }\end{array}$ & $\begin{array}{l}14 \text { Physiotherapists: } 8 \text { at } \\
\text { rehabilitation facility and } 6 \text { at } \\
\text { acute care facility }\end{array}$ & $\begin{array}{l}\text { Focus groups (using } \\
\text { semi-structured } \\
\text { questions) were } \\
\text { conducted to explore } \\
\text { perceptions about } \\
\text { treadmill training } \\
\text { during inpatient stroke } \\
\text { rehabilitation. } \\
\text { These were recorded, } \\
\text { transcribed, coded and } \\
\text { analysed thematically. }\end{array}$ & $\begin{array}{l}\text { Themes: } \\
\text { Treadmill training potentially } \\
\text { beneficial for function \& early } \\
\text { walking practice. } \\
\text { Mixed perceptions on } \\
\text { walking quality/normal gait } \\
\text { pattern. } \\
\text { Factors influencing use of } \\
\text { treadmill: } \\
\text { - patient comorbidities \& } \\
\text { ability } \\
\text { - safety \& resources } \\
\text { - culture \& organisation } \\
\text { - access to training } \\
\text { - encouragement }\end{array}$ \\
\hline $\begin{array}{l}\text { Wiles et al, } 2008 \\
\text { [65]; United } \\
\text { Kingdom }\end{array}$ & $\begin{array}{l}\text { Qualitative } \\
\text { methodology: }\end{array}$ & $\begin{array}{l}\text { Exercise on } \\
\text { Prescription (EoP) } \\
\text { schemes in leisure }\end{array}$ & $\begin{array}{l}9 \text { People post-stroke } \\
\text { participating in EoP schemes. }\end{array}$ & $\begin{array}{l}\text { Fitness instructors', } \\
\text { physiotherapists' and } \\
\text { patients' perspectives }\end{array}$ & $\begin{array}{l}\text { Most patients referred to EoP } \\
\text { were men. } \\
\text { Main themes: }\end{array}$ \\
\hline
\end{tabular}




\begin{tabular}{|c|c|c|c|c|c|}
\hline & $\begin{array}{l}\text { Focus groups and } \\
\text { interviews }\end{array}$ & $\begin{array}{l}\text { centres in urban, } \\
\text { rural and } \\
\text { suburban areas }\end{array}$ & $\begin{array}{l}6 \text { Fitness instructors running } \\
\text { the schemes including one } \\
\text { scheme coordinator } \\
15 \text { Physiotherapists who can } \\
\text { refer patients to these } \\
\text { schemes. }\end{array}$ & $\begin{array}{l}\text { about EoP schemes for } \\
\text { people post-stroke } \\
\text { explored through } \\
\text { interviews with the } \\
\text { stroke patients, fitness } \\
\text { instructors and two of } \\
\text { the physiotherapists } \\
\text { and focus groups with } \\
13 \text { of the } \\
\text { physiotherapists. }\end{array}$ & $\begin{array}{l}\text { - Method of continuing with } \\
\text { physiotherapy post-discharge } \\
\text { from NHS } \\
\text { - safety (knowledge, training } \\
\text { about stroke, equipment, } \\
\text { patient ability). } \\
\text { - supervision, support and } \\
\text { interaction during } \\
\text { participation } \\
\text { - collaboration between } \\
\text { fitness instructors and } \\
\text { physiotherapists, } \\
\text { Barrier: training and funding } \\
\text { Comparison of patients' } \\
\text { perceptions with those of } \\
\text { physiotherapists and fitness } \\
\text { instructors. }\end{array}$ \\
\hline $\begin{array}{l}\text { *Zinger et al, } \\
2011[60] ; \\
\text { Netherlands }\end{array}$ & Questionnaire & $\begin{array}{l}\text { Rehabilitation } \\
\text { facilities- } \\
\text { hospitals, } \\
\text { rehabilitation } \\
\text { centres and } \\
\text { nursing homes }\end{array}$ & $\begin{array}{l}186 \text { Team members of the } \\
\text { rehabilitation facilities }\end{array}$ & $\begin{array}{l}\text { Exercise guide to } \\
\text { increase exercise } \\
\text { intensity for people } \\
\text { post-stroke was } \\
\text { developed with } \\
\text { therapists and } \\
\text { rehabilitation facility } \\
\text { team members } \\
\text { regarding content, } \\
\text { format and } \\
\text { implementation. }\end{array}$ & $\begin{array}{l}\text { Decision to create } 2 \text { versions: } \\
\text { 1) Ready-to-use version } \\
\text { categorising exercise levels } \\
\text { for hospital use } \\
\text { 2) Customisable version for } \\
\text { individual exercise } \\
\text { prescription for use in } \\
\text { nursing homes and } \\
\text { rehabilitation centres. }\end{array}$ \\
\hline
\end{tabular}


Table 3: Factors Identified as Influencing the Implementation of Aerobic Exercise in Stroke

\begin{tabular}{|c|c|}
\hline \multicolumn{2}{|c|}{ INTERVENTION CHARACTERISTICS } \\
\hline Adaptability & $\begin{array}{l}\text { - Exercise can be adapted for stroke patients needs through equipment, changing the environment, and presence } \\
\text { of specialist or additional staff }[49,51,53,57,60,61,63,66]\end{array}$ \\
\hline Complexity & $\begin{array}{l}\text { - The steps required prior to implementation (screening) }[37,54,61,63,66] \\
\text { - The number of (potential) professionals involve }[37,52,55,61,66]\end{array}$ \\
\hline $\begin{array}{l}\text { Design Quality \& } \\
\text { Packaging }\end{array}$ & - Prescriptiveness and format of the aerobic exercise influences if and how it is implemented[60,63] \\
\hline Cost & - Costs for implementation includes staff, training, equipment and environment $[51,53,55,62,65]$ \\
\hline \multicolumn{2}{|l|}{ OUTER SETTING } \\
\hline $\begin{array}{l}\text { Patient Needs \& } \\
\text { Resources }\end{array}$ & $\begin{array}{l}\text { - Physical and cognitive needs, safety and perceived risk to the patient }[37,38,49-52,54-60,63-66] \\
\text { - Social and cultural factors }[37,66] \\
\text { - Accessibility of services }[38,52,53,55,56,62]\end{array}$ \\
\hline Cosmopolitanism & $\begin{array}{l}\text { - Networking and skill-sharing between organisations, such as between physiotherapists and fitness instructors } \\
{[51,53,65]}\end{array}$ \\
\hline \multicolumn{2}{|l|}{ INNER SETTING } \\
\hline $\begin{array}{l}\text { Structural } \\
\text { Characteristics }\end{array}$ & $\begin{array}{l}\text { - Service organisation and staffing }[37,38,53,55,61,64] \\
\text { - Geographical coverage of services }[52,56] \\
\text { - Funding models }[55,63] \\
\text { - Service provision for the stroke population }[55-57,63]\end{array}$ \\
\hline
\end{tabular}




\begin{tabular}{|c|c|}
\hline $\begin{array}{l}\text { Networks \& } \\
\text { Communications }\end{array}$ & - Communication and collaboration between professionals within organisations $[53,56,63]$ \\
\hline Compatibility & $\begin{array}{l}\text { - How implementation fits within the individuals' role, responsibilities and workflow and the method for onward } \\
\text { referral to other services or professionals }[37,38,49,51,53,63,65,66]\end{array}$ \\
\hline Relative Priority & $\begin{array}{l}\text {-Perceived as desirable with an identified willingness to facilitate through training, }[55,65] \text { e.g. physios providing } \\
\text { training on stroke to fitness instructors in the Exercise on Prescription setting. }\end{array}$ \\
\hline $\begin{array}{l}\text { Organizational } \\
\text { Incentives \& } \\
\text { Rewards }\end{array}$ & $\begin{array}{l}\text { - Provision of funding for training and professional certification in the area of stroke for exercise professionals would } \\
\text { be an incentive. }[51,63,65]\end{array}$ \\
\hline Available Resources & $\begin{array}{l}\text { - Available resources included staff, training, equipment, physical space, accessibility to screening and exercise } \\
\text { testing and funding for these. }[37,38,49-53,55-59,61-63,65,66]\end{array}$ \\
\hline $\begin{array}{l}\text { Access to Knowledge } \\
\& \text { Information }\end{array}$ & $\begin{array}{l}\text { - Communication within organisations and knowledge-sharing between both professionals and services } \\
{[38,51,54,56,64,66] \text {. }}\end{array}$ \\
\hline \multicolumn{2}{|c|}{ CHARACTERISTICS OF INDIVIDUALS } \\
\hline $\begin{array}{l}\text { Knowledge \& Beliefs } \\
\text { about the } \\
\text { Intervention }\end{array}$ & $\begin{array}{l}\text { - Generally agreed that aerobic exercise was important and should be prescribed post-stroke }[37,38,50,57,59,64,65] \\
\text { - Not all staff possessed factual knowledge about the intervention }[38,50,51,54,57,65] \\
\text { - Concerns about their patients' ability and motivation to participate in aerobic exercise }[37,38,52,58-60,65]\end{array}$ \\
\hline Self-efficacy & $\begin{array}{l}\text { - Individuals' confidence in their abilities to prescribe aerobic exercise to people post-stroke varied } \\
{[38,50,51,56,59,65,66]} \\
\text { - Some fears of liability or making the patient worse }[51,64]\end{array}$ \\
\hline $\begin{array}{l}\text { Other Personal } \\
\text { Attributes }\end{array}$ & $\begin{array}{l}\text { - Individuals displayed an interest and willingness to upskill in order to implement aerobic exercise for this } \\
\text { population }[50,51,55,56,65,66]\end{array}$ \\
\hline
\end{tabular}


